Golden Gate University School of Law

GGU Law Digital Commons

$1-1-2022$

WHAT TO DO WITH LEFTOVERS: COLLECTING EARMARKED

DONATIONS THROUGH MOBILE PAYMENT APPS

Mary Scott Polk

Follow this and additional works at: https://digitalcommons.law.ggu.edu/tax-estate-planning-review

Part of the Estates and Trusts Commons, Taxation-Federal Estate and Gift Commons, and the Tax Law Commons 


\title{
WHAT TO DO WITH LEFTOVERS: COLLECTING EARMARKED DONATIONS THROUGH MOBILE PAYMENT APPS
}

$\square$ January 1, 2022

IIII Articles, Charitable Contribution, Charitable Deduction, Mobile Payments, Online Payments, Overfunded Charities, Privacy

D USTC

F MaryScott Polk

0 comments

\begin{abstract}
With the rise in mobile payment applications, charitable donations using these platforms are increasing; equally, the use of a conduit between a donor and a charity to solicit and collect donations for the charity's benefit is growing. If a charity is overfunded or the charitable purpose is no longer available, the conduit is caught holding a pool of designated donations without the ability to contact the donors for permission for a similar or alternate use. Using the Internal Revenue Code requirements, the authority and regulations are not apparent for a charitable contribution through a conduit, particularly not for a conduit's use of a mobile payment application.
\end{abstract}

Part I of this Article provides an overview of the conduit situation and the complications that arise. Part II introduces the requirements of a charitable contribution and the services that mobile payment applications offer. Part III analyzes three donation methods: a contribution directly to a 501(c)(3) organization, a contribution to an individual, and a contribution to a 501(c) (3) organization through an individual. Part IV examines the potential solutions to the issue of overfunded charities and the motivations behind each. Finally, Part V offers a brief overview of the prevalence of the issue and the future of mobile payment applications. The interaction of the 
detailed requirements of the Internal Revenue Code for a charitable contribution and mobile payment applications' privacy policies, without clear authority or direction on the specific conduit situation, has the potential to be problematic and challenging for the contributor, conduit, charitable organizations, and mobile payment applications.

\section{TABLE OF CONTENTS}

- I. INTRODUCTION

- II. BACKGROUND

- A. Requirements to be a Charitable Contribution

- B. Electronic Fund Transfers

- C. Online Payment Services

- III. PROBLEM: OVERFUNDED CHARITIES

- A. Contribution to a 501(c)(3) Organization

- B. Targeted Contributions

- i. Limitations on Donor Control

- ii. Contribution to an Individual

- C. Charitable Conduit: Contribution to a 501(c)(3) Organization Through an Individual

- i. Timing

- ii. Mobile Payment Applications

- iii. Communication Certainty: Overfunded Charity

- iv. Communication Uncertainty: Overfunded Charity

- v. Privacy Dilemma

- IV. SOLUTION

- A. Equitable Alternate Use

- B. Change in the Regulations

- C. Charity Announcement

- D. Conduit Self-Protection Provision

- V. CONCLUSION 


\section{INTRODUCTION}

John posted on his Facebook status, "I'm raising money for The Boys \& Girls Club of North Mississippi. They need funds to build a new gymnasium. If you want to help, I will be collecting donations via Venmo (@John_Doe).” John received many donations from his Facebook post from people like Jane, who saw John's Facebook post and paid John via Venmo with the subject line, "For The Boys \& Girls Club of North Mississippi gym.” Later, John went to deliver the funds he collected to The Boys \& Girls Club, and they told John that they had met their funding needs for the gymnasium and did not need any more. With donations like Jane's donated specifically for The Boys \& Girls Club of North Mississippi's gymnasium, what does John do with the leftover funds?

Similarly, Jane is the treasurer for an organization on campus. In her duty as treasurer, she must collect all of the donations that the organization receives during their big fundraising week through her Venmo account. Last year, the organization raised $\$ 30,000$ for a children's shelter, meaning Jane had $\$ 30,000$ in her Venmo account. The organization presented the money to the children's shelter at the start of the new year. If Jane had $\$ 30,000$ sitting in her Venmo account, does she have to report it as income on last year's tax return? Likewise, would a person who donated to the organization during the fundraising week last year get a tax deduction on last year's tax return or not until the new year?

Generally, when an individual, the contributor, transfers money to another individual using a mobile payment application, the second individual, who transfers money to the charity, becomes a conduit on behalf of the contributor. The donation will be deductible to the contributor when the conduit transfers the funds to the charity. ${ }^{1}$

What happens when this well-intentioned conduit collects funds for a charitable purpose that is overfunded before the money is transferred to the charity? When a charity has collected sufficient funds for the charitable purpose, the charity returns those funds to the contributor. In the conduit situation, however, the question is what should the conduit do with those funds. This Article will address the problematic interaction between the Tax Code requirements and the difficulty in returning the funds received in the conduit situation. 


\section{BACKGROUND}

If a taxpayer donates to a charity, they are entitled to a deduction for their donation for income tax purposes if the Internal Revenue Code ("I.R.C.") requirements are satisfied. ${ }^{2}$ The Internal Revenue Service implements the rules and regulations under the I.R.C. for charitable contribution deductions. Title 26 of the U.S. Code is the I.R.C., codifying the federal tax laws. ${ }^{3}$ In the I.R.C., different sections provide statutory law for different parts of taxation. For instance, Section 170 covers charitable contributions and the requirements that must be satisfied to get a deduction. ${ }^{4}$ To satisfy the requirements under Section 170 , the contribution must be: made to a charitable organization listed in Section 501; paid in the current taxable year; and less than $\$ 250$, unless the charity acknowledges the contribution. ${ }^{5}$ Even if the requirements under Section 170 are satisfied, the amount a taxpayer is entitled to deduct is limited based on the taxpayer's taxable income, the type of contribution, and the recipient of the contribution. ${ }^{6}$ Similarly, Section 501 enumerates the organizations that will be considered exempt from taxation and the conditions that must be fulfilled. ${ }^{7}$ In summary, each contribution that a taxpayer is seeking a deduction for must satisfy the requirements of Section 170, and the amount of the deduction must be determined by the preceding factors and limitations. ${ }^{8}$

A nonprofit organization and a tax-exempt qualifying organization differ in the rules that regulate them. A nonprofit is an organization without a financial benefit and incorporated under state law. ${ }^{9}$ A tax-exempt organization follows the I.R.C. federal laws. ${ }^{10}$ Organizations included in Section 501(c)(3) are charitable organizations and exempt from taxation. ${ }^{11}$

Before determining a taxpayer's entitlement to a deduction under Section 170, taxpayers must first donate to a charitable organization. ${ }^{12}$ There are various means to make donations to charities. In the past few years, online payment services have become a new way to donate through electronic fund transfers. Because of the secure and simple, user-friendly online payment platforms, they have become increasingly popular. ${ }^{13}$

\section{A. REQUIREMENTS TO BE A CHARITABLE CONTRIBUTION}

When a person donates money or property to a charitable organization, the donor can deduct the contributions for income tax purposes. ${ }^{14}$ Charitable contributions are defined as "a 
contribution or gift to or for the use of" a qualifying organization. ${ }^{15}$ For an organization to be a qualifying organization under Section 170 (c), it must be:

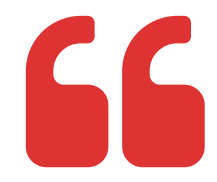

A corporation, trust, or community chest, fund, or foundation - . . created or organized in the United States or in any possession thereof, or under the law of the United States, any State, the District of Columbia, or any possession of the United States; ... organized and operated exclusively for religious, charitable, scientific, literary, or educational purposes, or to foster national or international amateur sports competition (but only if no part of its activities involve the provision of athletic facilities or equipment), or for the prevention of cruelty to children or animals; ... no part of the net earnings of which inures to the benefit of any private shareholder or individual; and ... which is not disqualified for tax exemption under section 501(c)(3) by reason of attempting to influence legislation, and which does not participate in, or intervene in (including the publishing or distributing of statements), any political campaign on behalf of (or in opposition to) any candidate for public office.

A contribution or gift by a corporation to a trust, chest, fund, or foundation shall be deductible by reason of this paragraph only if it is to be used within the United States or any of its possessions exclusively for purposes specified in 


\section{subparagraph (B). Rules similar to the rules of section 501(j) shall apply for purposes of this paragraph. ${ }^{16}$}

Within I.R.C. Section 170, a contribution or gift is a voluntary payment that is "made with no expectation of procuring a financial benefit" corresponding to the intention for the donation or amount of the contribution. ${ }^{17}$ Donations for the benefit of a designated individual are not deductible as charitable contributions under Section $170 .{ }^{18}$

A donation is not a gift if the payment is made out of an obligation, future benefit, or exchange of services. ${ }^{19}$ In Comm'r v. Duberstein, the taxpayer received the gift of a car in return for the information the taxpayer revealed. ${ }^{20}$ The Court looked at the donative intent and held that a gift must be made out of a "detached and disinterested generosity." 21 In determining whether a transfer is a charitable contribution, the Court examines the donor's "dominant motive" when applying Duberstein's detached and disinterested generosity standard. ${ }^{22}$ In Allen v. U.S., the taxpayer's dominant motive in a transaction of acres of redwoods deeded to the city was preserving the redwoods. ${ }^{23}$ Therefore, the purpose and intent of a donation must be for a public benefit and to a qualifying organization for a donation to be a charitable contribution. ${ }^{24}$

\section{B. ELECTRONIC FUND TRANSFERS}

A charitable contribution is made in cash, check, or a monetary gift, including transfers of gift cards redeemable for cash and payments by credit cards, electronic fund transfer, online payment service, or payroll deductions. ${ }^{25}$ An electronic fund transfer is simply a transfer of money from one bank account to another bank account. ${ }^{26}$ An online payment service is a platform that has the technology to enable payment transactions electronically. ${ }^{27}$

\section{ONLINE PAYMENT SERVICES}

Mobile payment applications are online services that act as an alternative method of payment. ${ }^{28}$ Examples of mobile payment applications that use electronic fund transfers are Venmo, Cashapp, and PayPal. ${ }^{29}$ These applications are online payment services that act as a digital wallet. You will connect your credit or debit card or your bank account to the 
application, and it will allow you to pay and receive money directly through the platform. These applications allow users to download, register, and make a transfer within minutes. An individual can transfer funds from their bank account or credit card to another user on the application. The second user can set up their bank account and transfer the funds to their bank account. The users can pay, accept, and exchange money for goods and services. ${ }^{30}$ With the flexibility of online payment services, millions of people are joining the platforms, and even more money is being transferred. ${ }^{31}$ Online fundraising through payment services has become popular among charities and donors. ${ }^{32}$ Particularly, the practice of crowdfunding to collect small payments from many individuals to raise money through the use of social media and mobile payment applications has grown quickly. ${ }^{33}$ The interaction of the requirements for charitable deductions and the privacy aspects of online payment services creates a complex web of rules for someone who acts as a conduit to collect and pay over funds to a charitable organization.

\section{PROBLEM: OVERFUNDED CHARITIES}

In the John Doe fact pattern above, if The Boys \& Girls Club of North Mississippi's new gym project's needs have been fulfilled, or The Boys \& Girls Club chose not to proceed with the project, what does John do with the donations? ${ }^{34}$ Similarly, in the Jane example, what will she do with the $\$ 30,000$ in donations collected from last year's fundraising week ${ }^{35}$ The answers differ in the following situations: a contribution to a charitable organization, a contribution directly to an individual, or a contribution to a charitable organization through a conduit.

\section{A. CONTRIBUTION TO A 501(C)(3) ORGANIZATION}

An organization is tax-exempt if it is included within Section $501(\mathrm{c})(3) \cdot{ }^{36}$ For an entity to be recognized as a 501 (c)(3) organization, it must apply to the Internal Revenue Service ("IRS") by submitting Form 1023 for approval by the IRS. ${ }^{37}$ Contributions to 501 (c)(3) organizations are tax-deductible; moreover, the organization is exempt from taxation. ${ }^{38} \mathrm{~A} 501$ (c)(3) organization, i.e., qualified charitable recipient, is "any community chest, fund, or foundation, organized and operated exclusively for religious, charitable, scientific, literary, or educational purposes..."39 For example, if an individual contributes to the American Red Cross, the individual would be 
allowed a deduction because the Red Cross has 501(c)(3) status and is tax-exempt. The term "charitable" used in Section 501(c)(3) refers to the common law interpretation of the term and includes:

Relief of the poor and distressed or of the underprivileged; advancement of religion; advancement of education or science; erection or maintenance of public buildings, monuments, or works; lessening of the burdens of Government; and promotion of social welfare by organizations designed to accomplish any of the above purposes, or (i) to lessen neighborhood tensions; (ii) to eliminate prejudice and discrimination; (iii) to defend human and civil rights secured by law; or (iv) to combat community deterioration and juvenile delinquency. ${ }^{40}$

Consequently, a donation to the American Red Cross is charitable because it provides emergency assistance and relief to people affected by disasters.

To be a 501(c)(3) organization, the organization must satisfy the organizational and operational tests in the I.R.C. ${ }^{41}$ An organizations' articles stating that it was formed for charitable purposes is sufficient to meet the organizational test. ${ }^{42}$ To meet the operational test, an organization will be operated exclusively for an exempt purpose, only if it is primarily involved in activities that accomplish an exempt purpose. ${ }^{43}$ Alternatively, an organization will not be operated exclusively if "more than an insubstantial part" of its activities are not for an exempt purpose. ${ }^{44}$ Further, the organizational and operational tests are not satisfied unless the organization serves a public interest. ${ }^{45}$

\section{B. TARGETED CONTRIBUTIONS}

Often when people donate money to a charity, they want to control their funds and designate them for a particular purpose. They can accomplish this by selecting a charity with that purpose. Sometimes donors can designate their funds to specific areas within that charity. Once the donation is transferred to the charity, however, the charity, not the donor, must have control over the funds. ${ }^{46}$ The charity must have sufficient control to satisfy the "to or for the use of" a qualified organization standard. ${ }^{47}$ If the donation is made to a specific individual, the charity does not have control over the donated funds to satisfy the "to or for the use of" a qualified organization standard. ${ }^{48}$ In this situation, the contribution is not deductible. ${ }^{49}$ 


\section{LIMITATIONS ON DONOR CONTROL}

When a person donates money to a charity, the donor can earmark the donation to be used for a particular charitable purpose. How specific can donor designations be? The donor has control over where their donations go by donating them to a specific charity that aligns with the donor's intent. For example, you can donate to the University of Mississippi School of Accounting, designating it to the school to be used however they wish, or you can donate to the University of Mississippi Athletics and specifically designate it to be used in building a new football stadium. Within the specific charities, you can designate use or to a group of beneficiaries. For example, an individual can donate funds to the American Red Cross and specify, "I want to support" victims of the western wildfires. ${ }^{50}$ Therefore, those donations are earmarked and will aid in relief for the victims of the western wildfires.

In Peace v. Commissioner of Internal Revenue, the taxpayer made contributions to a religious organization but named specific individuals. ${ }^{51}$ There were three types of donations to the religious organization: general undesignated funds, funds for support, and special funds. ${ }^{52}$ General undesignated funds were for current expenses of the organization, and special funds were "gifts designated for special projects and personal transmission gifts sent directly to the missionaries concerned." 53 The court held that the taxpayer's intention was not for the donations to go directly to the individuals but rather placed in a common pool subject to the organization's control. ${ }^{54}$ Under their policy, the organization had exclusive control of the donated funds and, therefore, were deductible. ${ }^{55}$

Further, the charity must maintain control over the donor's funds to qualify for a deduction. ${ }^{56}$ In Brinley v. Comm'r, the court held that the church does not have to maintain full control over the funds; rather, the control test was satisfied by non-possessory control of the church maintaining discretion as to the use of the funds. ${ }^{57}$ The Brinley court argued that when a charity solicits funds for a specific charitable purpose, possessory control is not required. ${ }^{58}$ However, the Supreme Court disagreed. In Davis v. U.S., the Court adopted a possessory control test that requires a charity to have control over the funds to qualify for a deduction. ${ }^{59}$ Davis overruled courts that adopted a non-possessory control test and held that the transfer of funds to the taxpayers' sons was not "to or for the use of" the Church and did not satisfy the control test. ${ }^{60}$ The Court looked to Congress's intent to interpret the "to or for the use of" phrase when enacting Section 170: 


\section{$\int$ Congress sought to provide tax benefits to charitable organizations, to encourage the development of private institutions that serve a useful public purpose or supplement or take the place of public institutions of the same kind. ${ }^{61}$}

Congress amended Section 170 to overcome the interpretation that disallowed a deduction for contributions to a charity made in trust for that organization.

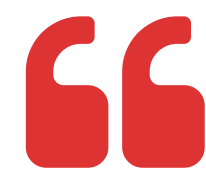

Moreover, a contribution made in trust for a charity does not give the charity immediate possession and control, as does a donation directly to a charity. Unlike a contribution that must go "to" a qualified organization, a contribution "for the use of" a donee may go to a trustee with the discretion to select among a number of qualified donees to whom the funds may be disbursed. ${ }^{62}$

If the donor does not receive a quid pro quo, an advantage or benefit in exchange for their contributions, the transaction satisfies the charitable contribution or gift requirement. ${ }^{63}$ In Davis, the ninth circuit held that the parent taxpayers did receive a quid pro quo in the assurance that their missionary sons would be taken care of and that the sons received an economic benefit because the payments were used for their proper care. ${ }^{64}$ This meant that the Church was not the primary beneficiary from the transfer and did not satisfy the "to or for the use of" requirement. ${ }^{65}$ 
There is no deduction under Section 170 for the contribution of services, but Treasury Regulation Section 1.170A-1(g) provides, "unreimbursed expenditures made incident to the rendition of services to an organization contributions to which are deductible may constitute a deductible contribution." "The Davis Court emphasized that the deduction allowed by Section $1.170 \mathrm{~A}-1$ (g) pertains to the individual taxpayer's "unreimbursed expenditures" to their own contribution of services to an organization and not to a third party. ${ }^{67} \mathrm{It}$ feared that the parent taxpayers' interpretation of Section 1.170A-1(g) as allowing third parties a deduction would promote a manipulation for tax evasion and impose a heavy administrative burden on the IRS. ${ }^{68}$

\section{CONTRIBUTION TO AN INDIVIDUAL}

Charitable contributions given directly to or earmarked for a specific individual not possessed by a charity are not deductible. ${ }^{69}$ Therefore, if a charity or qualified organization is not the recipient of a contribution but rather an individual, the contribution is not deductible. ${ }^{70}$ For example, if an individual collected donations through a GoFundMe page for an individual, the issues that arise are whether the donor is entitled to a deduction and whether the recipient has an income. ${ }^{71}$ In this situation, the donor would not be entitled to a deduction because the contribution is not to a qualifying charitable organization but rather to a designated individual. ${ }^{72}$ The test for gross income comes from the holding in C.I.R. v. Glenshaw Glass Co. ${ }^{73}$ Under the Glenshaw Glass $^{74}$ test for gross income, the recipient would include the donations in gross income. ${ }^{75}$ However, the contributions to the recipient would not be included in the recipient's gross income because the contributions are a gift, and gifts are specifically excluded from gross income. ${ }^{76}$ What if James lost his belongings in a house fire and you gave his family money to help with repairs and other costs? The transfer is a gift, so the recipient will not have gross income, ${ }^{77}$ but the donor will not be entitled to a deduction. ${ }^{78}$ There are complexities regarding what is treated as a gift and limitations on the exclusion from gross income, but that discussion is beyond the scope of this Article.

This denial of deduction extends to situations where a charity is used as a conduit to funnel benefits to the contributor. In DeJong v. Commissioner, a nonprofit corporation ran a school that did not charge tuition but raised its funds from parents of enrolled students, churches, members, and other people. ${ }^{79}$ The contributions to the nonprofit were placed in the undesignated general operating fund. ${ }^{80}$ Here, the taxpayer's children were students of the 
school, and the taxpayer contributed to the nonprofit. The parents deducted their contribution on their tax return. ${ }^{81}$ The court held that the amount contributed for the estimated cost of educating the taxpayers' children was intended as tuition payments for their children's education and did not constitute a charitable contribution. ${ }^{82}$

In Haak v. United States, the members would pay the Church, who would pay the local Christian schools the amounts equal to the cost of educating the parent members' children. ${ }^{83}$ The court agreed with the Service that the payments made to the Church in the amount of the cost for their children's tuition were not "contribution(s) or gift(s)," but rather payments for education and did not constitute a charitable contribution. ${ }^{84}$ In both DeJong and Haak, children were not refused admission for failure to pay by the parents or the church, respectively. ${ }^{85}$ However, the payments were expected and did not constitute charitable contributions. ${ }^{86}$

\section{CHARITABLE CONDUIT: CONTRIBUTION TO A 501(C)(3) ORGANIZATION THROUGH AN INDIVIDUAL}

Revisiting the John Doe example, John collecting contributions through his Venmo account to later transfer to The Boys \& Girls Club of North Mississippi is the act of a conduit. ${ }^{87}$ Individuals can collect charitable contributions from donors and then forward them to charities, acting as a conduit. ${ }^{88}$ In this situation, contributors will receive deductions from their income for their charitable contribution. ${ }^{89}$ The individual acting as the conduit will not have any income from the solicitations held by the conduit solely for payment to the charity.

In Glenshaw Glass, the Court held that taxpayers have gross income when (1) they have undeniable accession to wealth, (2) the wealth is clearly realized, and (3) the taxpayers have complete dominion over the wealth. ${ }^{90}[4]$ The conduit does not have an accession to wealth because the conduit does not benefit from the funds; the wealth may be clearly realized, but the conduit does not have dominion over the wealth because they are merely holding the funds until the transfer to the charity. ${ }^{91}$

The conduit is merely holding the excess funds for the charity's benefit and, therefore, does not have any gross income. One avenue that the conduit could use to ensure that the funds collected would not be included in gross income is to place the funds in a special trust, similar 
to Ford Dealers Advertising Fund, Inc. v. Comm'r of Internal Revenue. ${ }^{92}$ The excess funds were placed in a special trust that allowed the conduit to avoid being taxed on income. ${ }^{93}$ In Ford Dealers, a nonprofit corporation that received earmarked funds to be used solely for advertising purposes held the funds received "in trust," with no gain in profit or gain accruing to the taxpayer, and are excluded from gross income. ${ }^{94}$ The nonprofit corporation argued that they "served merely as a conduit or agent for forwarding" the funds to the advertising media. ${ }^{95}$ However, a conduit does not need to go through the trouble of setting up a formal trust to avoid including the funds in gross income as long as the conduit holds the excess funds intending to transfer it to or for the benefit of a charity. ${ }^{96}$ Accordingly, if a conduit collects funds through their Venmo account designated for a charity, and the funds are held for the charity's exclusive use, the funds are excluded from gross income. ${ }^{97}$

\section{TIMING}

In the conduit situation, when will the contributor get a deduction ${ }^{98}$ In Jane's case, if the organization does not donate the funds collected during last year's fundraising week to the shelter until the start of the new year, will the contributors get a tax deduction in the year they donated or the next? ${ }^{99}$ A deduction is allowed for a charitable contribution within the taxable year the contribution is paid. ${ }^{100}$ Determining when the contributor is allowed the deduction depends on when the conduit sends the contributions to the charity. ${ }^{101}$ What happens if Taxpayer A gives money to Taxpayer B and Taxpayer B gives money to the charity in tax year 1 ? Taxpayer $A$ gets the deduction in year 1 because the contribution was paid to the charity in tax year 1 . Taxpayer B, acting as a conduit, has neither gross income nor a deduction. ${ }^{102}$

What happens if Taxpayer A gives money to Taxpayer B and Taxpayer B does not give the charity money until tax year 2? Taxpayer $A$ does not get the deduction in tax year 1 because the contribution has not yet been made to the charity, and only when a contribution is "actually paid during the taxable year" to a charitable organization will Taxpayer A be entitled to a deduction. ${ }^{103}$ It is still in the hands of Taxpayer B. Taxpayer B still does not get a deduction because they are simply forwarding the contributions to the charity. ${ }^{104}$ Correspondingly, the contributors who donated to the children's shelter through Jane's organization would not get a deduction until the funds were given to the shelter in the new year. Jane is Taxpayer B in this situation and does not get a deduction because she is simply a conduit and not the intended 
beneficiary. ${ }^{105}$ This is important because the taxpayer needs to know what tax year to file their deduction. ${ }^{106}$

The conduit needs to get the funds into the hands of a charitable organization within the same taxable year that the contributor gave the funds to the conduit. This capability will fix a problem sequence that will occur in the conduit situation with an overfunded charity. First, if the charity does not take the funds from the conduit at all, then the timing becomes an issue because if the charity does not take it, the conduit would still have the funds at the close of the taxable year. Now, the contributor does not get their deduction in the first taxable year. However, the contributor may not know that they do not get their deduction in the first taxable year because they had already turned over their funds to the conduit during the first taxable year. Therefore, the contributor could incorrectly claim a deduction when they filed their tax return for the first taxable year. ${ }^{107}$

\section{MOBILE PAYMENT APPLICATIONS}

Often, people will post requests for donations on their social media pages. ${ }^{108}$ These donations are processed through their mobile payment accounts. The individual collects the funds to transfer them to charitable organizations. In this situation, the individual acts as a conduit for the charity. These donations would still be tax-deductible to the contributor who transfers funds to the conduit for retransfer to the charity.

For example, an individual, who is not an employee or representative of a charity, posted a status on their Facebook page requesting donations for a specific charity. The individual's Facebook friends send payments via their personal Venmo account to the individual's personal Venmo account. The purpose of the payments is named by the contributors on the subject line required by Venmo. The individual will take the funds collected through Venmo and transfer the funds to the specific charity, acting as a conduit.

The tax implications for those using mobile payment applications are the same for those donating directly to a charity. If the charity needs the donations, the contributor will get a deduction for the donation. The conduit who collects the funds will forward the donations and will not have gross income because the conduit did not receive a gain or loss from the transaction. 


\section{COMMUNICATION CERTAINTY: OVERFUNDED CHARITY}

What happens if the charity is no longer in need of donations? If a charity receives more funds than needed for a certain cause, then the charity is overfunded. If the charity receives more donations than it needs for its charitable purposes, the charity must contact its donors and ask permission to use them for a different purpose or return the funds to the donor. ${ }^{109}$ In Adler $v$. $S A V E$, the donors made an earmarked contribution to a nonprofit animal shelter to construct rooms exclusively for the care of larger dogs and older cats. ${ }^{110}$ The Court held that the animal shelter breached its fiduciary duty by disregarding the donor's expressed conditions and not returning the gift. ${ }^{111}$

If a charity is overfunded or the charitable purpose is no longer available, there are three options for the charity. First, the charity could simply decline to accept the donation because they are overfunded. For example, if the local library received enough donations to meet their need for a new roof, the library can decline to accept donations that would be more than the need. Second, if they accepted in excess and realized later that they were overfunded, they could contact the donor and return them. Finally, if a contribution is made for a certain charitable purpose and originally or later on cannot be completed, it could be donated to a similar alternate use according to the donor's intentions. ${ }^{112}$ If several donations were made and the library realized later on that the donations were more than the library's need for a new roof, then the library could use those donations to repair other exterior parts of the building, as this would be a similar alternate use.

\section{COMMUNICATION UNCERTAINTY: OVERFUNDED CHARITY}

In the conduit situation, complications arise when a charity declines to accept the conduit's collected amounts because they are overfunded. Similarly, in the preceding library example, a conduit collected donations for the library's roof, and then the library declined to accept them because it had satisfied their need. In this situation, the conduit would be holding a pool of funds specified for a particular charity where the charitable purpose no longer existed. The conduit must either return the funds to the contributor or ask for permission for the funds to be used in a different charitable way. ${ }^{113}$ With donations from the conduit's Facebook friends, this is not difficult because the conduit can contact them and ask for permission, either by Facebook messenger or through their personal contact information. ${ }^{114}$ 
Now, assume that the funds the conduit collects through Venmo are not just from their Facebook friends but also from unknown accounts. ${ }^{115}$ For example, if someone posted on their social media soliciting contributions and their friends share the post, then people on their friend list will have access to the post. Then, the friends of the friends can share the post so people on their friend list will have access to it. This process could happen any number of times; with the original post circulating the internet, countless people will see the post. ${ }^{116}$ This means that countless people will have the information to go to the initial person's Venmo account and contribute, whether the contributor knows the person soliciting donations or not.

The problem arises with this system when the charity declines to accept the contributions collected by the conduit. How does the conduit return the funds or ask for permission for the funds to be used for a different cause when the funds were received by unknown people? ${ }^{117}$ The conduit could return the funds via Venmo by transferring back the donated money to the contributor. ${ }^{118}$ This is not the most beneficial result because the contributor may not want their funds returned. The contributor may be committed to a certain kind of charitable function, or the contributors were really dedicated to that particular purpose and may want those funds to go to a similar purpose. The obligation to return the funds without an alternative opportunity could result in a lack of incentive for the contributors to donate those funds to another charity, leading to less overall charitable giving.

\section{PRIVACY DILEMMA}

The strict privacy policies with mobile payments, however, prevent easy communication between the contributor and conduit. An individual can go to a mobile payment site, such as Venmo, and set up an account within seconds. The requirements for a Venmo account are your first and last name, email address, phone number, password, Consent to Receive Electronic Disclosures and Agree to User Agreement and Privacy Policy. ${ }^{119}$ Mobile payment users' accounts can be linked to their bank account or credit or debit card with a small processing fee.

Transactions through mobile payment services have fraud, theft, and privacy risks. ${ }^{120}$ Venmo's policies respond to those privacy risks. According to Venmo's privacy policy, the application stores and processes information using third-party servers and safeguards that comply with federal and state regulations. ${ }^{121}$ With mobile payments, regulations governing traditional payments apply, but "there is still uncertainty about coverage and liability responsibilities." 
There is no specific agency that controls and governs mobile payments, but there are regulatory agencies that have "limited regulatory oversight."123

Venmo's interface and privacy settings are much more restrictive than an application such as Facebook. A Venmo account's contact information is not public information, so the conduit would not have access to the contributor's information. ${ }^{124}$ Additionally, there is no option to direct message an account on Venmo. ${ }^{125}$ The Treasury regulations are unclear about how the conduit would contact the contributor to request permission to use the funds for a different purpose. With no guidance on this situation, the conduit would be forced to return the funds without the option to request permission for a different charitable use. ${ }^{126}$

Assume the conduit found a similar charity in need of donations and gave the excess funds to them instead, even though the funds the conduit collected through Venmo were specified for a different charity. What happens if the contributor did not want their contribution to go to a similar charity but wanted their funds to go to the specified charity? Depending on the actions that the contributor plans to take, the conduit could find themselves in difficult circumstances. If a contributor made a large donation to a specific charitable purpose and the conduit donated the funds to a similar charity but not the specific one, the contributor could file suit against the conduit or the unintended charity for a variety of claims, including breach of fiduciary duty. ${ }^{127}$ The conduit has a fiduciary duty to the contributor because the contributor relied on the conduit to act in their donation's best interest. ${ }^{128}$ Similarly, the charity that accepted the designated funds that they knew were not intended for them could be liable.

\section{SOLUTION}

There is not a one size fits all solution for this problem. Any of the following potential solutions would be successful if implemented to protect the conduit, but various factors will be addressed that lead to the best option. While there are potential solutions to this problem, the actors with the ability to solve the problems lack the incentive to do so; however, there are options, such as an equitable alternate use clause, change in the regulations, announcement by the charity, and a conduit self-protection provision, that could clear up uncertainty. 


\section{A. EQUITABLE ALTERNATE USE}

The mobile payment application's user agreement could include a waiver or substitution clause with "equitable alternate use" language for charitable donations. This would allow the collector of charitable contributions to use excess funds in an equitable alternative way without gaining consent. The Venmo user agreement provides an update provision that states if the changes to the agreement reduce rights or increase responsibilities, there will be a notice of at least 21 days. ${ }^{129}$ Additionally, the user agreement states, "[b]y continuing to use our services after any changes to this user agreement become effective, you agree to abide and be bound by those changes." ${ }^{130}$ For example, the mobile payment application could provide the following language for the alternate use clause:

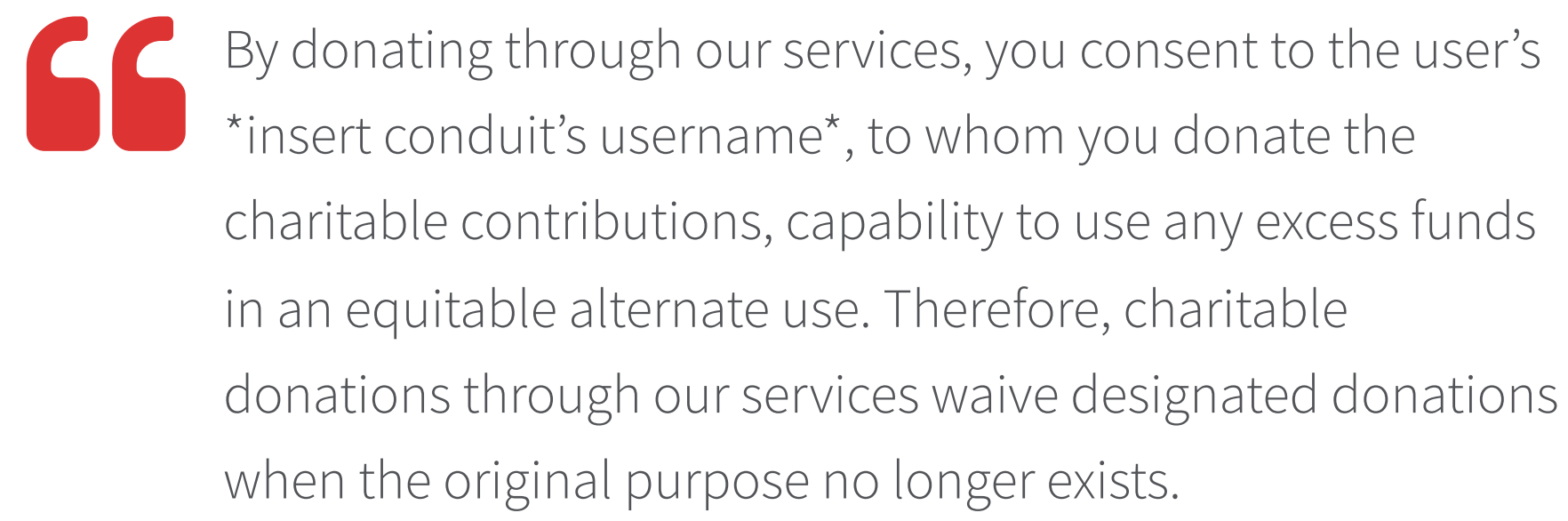

This clause would act as a waiver and allow the conduit to control the funds without having to gain consent if the charity did not accept the donations. Venmo's incentive to make an equitable alternate use provision would encourage their users to contribute to charities. However, Venmo's desire for their users to make charitable contributions is probably not strong enough for them to draft a special provision. Mobile payment applications doubtfully have an incentive to protect the conduit but rather themselves.

\section{B. CHANGE IN THE REGULATIONS}

The current regulations are not clear, nor do they distinguish rules for an individual acting as a conduit between the contributor and the charity. There could be an addition to the IRS 
regulations to allow for charities to accept and hold the contributions if they are overfunded until they find a similar use. Additionally, the regulations could provide that if the charity declined to accept donations because the charity was overfunded, the conduit could transfer to a similar use. Specifically, the provision could state the conduit has the control to transfer to a similar use for conduits when contributions are made using mobile payment applications, such as Venmo. In the special rule, it could allow for an equal or similar use. For example, the regulation could include the following language:

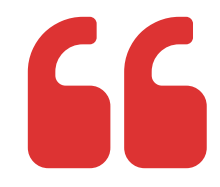

Unless otherwise provided by applicable regulations or other guidance published in the Internal Revenue Code, contributions to a charitable organization using a third party through a mobile payment application, rather than directly to the organization, are subject to an alternate but similar use if the original purpose is unavailable. Further, overfunded charitable organizations may accept excess earmarked donations and use the funds for a similar use.

The IRS has an incentive to put in a special rule because they want people to be able to contribute to charities. However, it could be difficult to get the IRS to recognize the problem and timely change the regulations.

\section{CHARITY ANNOUNCEMENT}

An alternative solution would be if the charity made a general announcement on their webpage stating the alternatives to earmarked donations if the charitable purpose no longer exists. For example, the announcement could include the language as follows: 
All earmarked donations will go to the *insert specified

purpose $^{\star}$ to the extent possible, and then to a similar

alternate purpose to the extent possible. Lastly, the

donations will then go to general charitable funds if the other alternatives are unavailable.

The only exception is that the contributor provided specific language stating otherwise at the time of donation, such as the specific request for return of funds if the earmarked purpose no longer exists. However, for donations through a conduit on mobile payments applications, the announcement on a charity's website might not be available to the contributor. The charity's incentive to make an announcement would be to raise money. However, the issue is that the contributor will not go to the charity's page; it is the conduit who goes to the charity's web page. Therefore, the charity announcement may not shield liability for the conduit because the contributor is not donating directly to the charity.

\section{CONDUIT SELF-PROTECTION PROVISION}

In an ideal world, one of the foregoing solutions would be implemented. However, a conduit protection provision is possibly the most logical and sensible action for the conduit situation. How do we fix this problem of the lack of information between the contributor and the conduit? Initially, how did the contributor know to give it to the conduit? The conduit, in some way, reached out to solicit the contributor. In the John example, he posted on Facebook requesting donations for The Boys \& Girls Club of North Mississippi's new gymnasium. ${ }^{131}$ Following his post, his friends shared the post, and then their friends shared the post. At this point, hundreds of people could have seen the request for donations all stemming from John's initial solicitation. Therefore, the conduit can control the information that the contributor sees prior to donation. For instance, the conduits could provide the following language on their social media post soliciting contributions: 


\section{If you forward money to me for *insert specific charity or charitable use* and that charity is overfunded or does not accept the contributions, I will give the funds to an alternate but similar use.}

This provision will put the contributor on notice that their funds will be used for an alternate similar use if the charity is overfunded. At this point, the contributors, at their discretion, may decide whether they are going to donate to the conduit. The provision will provide the conduits with the ability to use the pool of funds and assist worthy causes and protect themselves from liability.

\section{CONCLUSION}

According to I.R.C. Section 170, "[t]here shall be allowed as a deduction any charitable contribution ... payment of which is made within the taxable year." ${ }^{132}$ If a donor donated to a designated individual, the donor would not be entitled to a deduction because it was not for a public benefit and, therefore, not a charitable contribution. ${ }^{133}$ If an individual donated directly to a charitable organization, they would be entitled to a deduction when they made the donation. ${ }^{134}$ Correspondingly, in the conduit situation, the contributor's donation would be deductible within the taxable year that the conduit transferred the funds to the charity. ${ }^{135}$

If an individual solicited and collected funds for a charitable organization, the individual would be acting as a conduit between the donor and the charity. If the charitable organization becomes overfunded and the charitable purpose no longer exists, then the conduit must return the funds to the donors or ask permission for the contributions to be given to a different charitable organization. However, the latter option has been increasingly difficult when the conduit is collecting funds using a mobile payment application, such as Venmo, and does not have the donors' contact information. 
If a donor donates directly to a charity and the charity is overfunded, or the charitable purpose is no longer available, the charity must return the funds or ask permission for the funds to be used for a different purpose. ${ }^{136}$ Because the donor directly donated, the charity would reach out and ask permission for the funds to be used differently. In the conduit situation, it would be difficult to ask permission to donate the funds to a different charity through a mobile payment application because the applications do not offer contact information or an option to contact between users. For example, if John Doe solicited funds for the gymnasium for The Boys \& Girls Club of North Mississippi, John Doe is the conduit of the contributor's funds to The Boys \& Girls Club of North Mississippi. ${ }^{137}$ If The Boys \& Girls Club had collected sufficient funds for the gymnasium before the conduit had transferred the funds to them, the conduit needs to give the funds to an alternate, similar charitable organization within the same taxable year that the contributor gave the funds to the conduit.

Similarly, if Jane collected the money from last year's fundraising week, but the organization did not present the donations to the children's shelter until the start of the next calendar year, then the contributors during the fundraising week will not receive a deduction until the donation is transferred to the shelter. ${ }^{138}$ Further, Jane would not have to report the $\$ 30,000$ sitting in her Venmo account because she is a conduit and will not receive a financial benefit from the funds because the money will be transferred to the shelter. Jane did not have an accession to wealth, clearly realize, or exercise complete dominion over the money to be gross income. ${ }^{139}$

Correspondingly, there are solutions to the overfunded charity situation that will protect the conduit from liability. ${ }^{140}$ The potential solutions include a waiver in the mobile payment application's user agreement, a change in the regulations, an announcement by the charity, and a conduit self-protection provision. However, the actors in most of the proposed solutions lack the incentive to solve the issue. ${ }^{141}$ For the equitable alternate use provision, the mobile payment application's motivation to protect users and encourage contributions to charity is likely not strong enough to include a special provision for charitable donations. Second, the IRS has an incentive to change the regulations so that people will raise money for charities; however, the IRS may not recognize the issues and propose a timely change. Next, the charity making an announcement on their website is motivated by the desire to raise money, but the problem here is that the contributor may not visit the website and see the announcement 
because they donate through a conduit. Finally, the conduit self-protection provision is likely the most advantageous solution to the conduit situation with an overfunded charity.

In conclusion, the self-protection provision is the answer to the complications created by the interaction between the Tax Code requirements and the difficulty in returning the funds received in the conduit situation.

With the future of mobile payments, the use of online payment services will only continue to rise. Simplicity, convenience, and security are attractive qualities to an increasingly mobile world. As society gets more comfortable transferring large amounts of funds via mobile payment applications, legality issues are likely to arise due to the variety of situations previously described without clear authority or regulations. Being ahead and proactive on this matter will prove beneficial in the years to come.

1. I.R.C. $§ 170$ (2020) ("There shall be allowed as a deduction any charitable contribution... payment of which is made within the taxable year."). The taxable year that the charitable contribution is paid to the charity is when a deduction is allowed; for the conduit situation, the deduction is allowed within the taxable year that the conduit transfers the funds to the charity. $\longleftarrow$

2. To get a deduction, there must be a specific Internal Revenue Code section that entitles a deduction. Each section has requirements that must be satisfied and limitations that determine the amount of deduction. $\downarrow$

3. 26 U.S.C. (1986) (including all of the federal tax laws in the Internal Revenue Code).

4. I.R.C. $\S 170$ (2020) (including limitations for a taxpayer's deduction).

5. I.R.C. $§ 170,501$ (2020) (specifying that contributions to an individual will not be entitled to a deduction). $\longleftarrow$

6. I.R.C. $§ 170$ (2020). $\longleftarrow$

7. I.R.C. § 501 (2020).

8. I.R.C. § 170 (2020).

9. IRS, https://www.irs.gov/charities-non-profits/frequently-asked-questions-aboutapplying-for-tax-exemption (last visited Dec. 15, 2020).

10. I.R.C. $\S 501(c)(3)(2020)$. 
11. Id. ("Corporations, and any community chest, fund, or foundation, organized and operated exclusively for religious, charitable, scientific, testing for public safety, literary, or educational purposes, or to foster national or international amateur sports competition (but only if no part of its activities involve the provision of athletic facilities or equipment), or for the prevention of cruelty to children or animals, no part of the net earnings of which inures to the benefit of any private shareholder or individual, no substantial part of the activities of which is carrying on propaganda, or otherwise attempting, to influence legislation..., and which does not participate in, or intervene in (including the publishing or distributing of statements), any political campaign on behalf of (or in opposition to) any candidate for public office.").

12. I.R.C. § 170 (2020).

13. Nonprofit Fundraising Statistics, Double the Donation, https://doublethedonation.com/tips/matching-grant-resources/nonprofit-fundraisingstatistics/\#online (last visited Dec. 18, 2020) ("Online giving grew by $12.1 \%$ over the past year."). $\longleftarrow$

14. I.R.C. § 170 (2020) ("No deduction shall be allowed under subsection (a) for any contribution of a cash, check, or other monetary gift unless the donor maintains as a record of such contribution a bank record or a written communication from the done showing the name of the done organization, the date of the contribution, and the amount of the contribution."). $\downarrow$

15. Id. See, e.g., Johnny R. Buckles, The Case for the Taxpaying Good Samaritan: Deducting Earmarked Transfers to Charity Under Federal Income Tax Law, Theory and Policy, 70 Fordham L. Rev. 1243, 1246 (2002).

16. I.R.C. § 170 (2020). See I.R.C. §501(j) (2020). «

17. Hernandez v. C.I.R., 490 U.S. 680, 690 (1989). Rev. Rul. 83-104, 1983-2 C.B. 46. See I.R.C. § 170 (2020). See also Comm'r v. Duberstein, 363 U.S. 278, 285 (1960) (holding a "detached and disinterested generosity" standard to be a gift). $\longleftarrow$

18. I.R.C. $§ 170$ (2020). See Treas. Reg. §1.501(c)(3)-1(c)(2) (as amended in 2017) (explaining that the organization has the burden of establishing that it is not organized or operated for the personal benefit of a specific individual).

19. C.I.R. v. Duberstein, 363 U.S. 278, 285 (1960).

20. Id. $\longleftarrow$

21. Id. at 285-86 (explaining that the car's donative intent was not made out of detached and disinterested generosity, but rather to compensate for the information the taxpayer provided or to secure a future benefit). 
22. Allen v. U.S., 541 F.2d 786, 787 (9th Cir. 1976) (For a charitable deduction under I.R.C. § 170 , the definition of a gift in Duberstein has the same meaning for a contribution. The court found that a taxpayer, who deeded acres of redwoods to the City, was entitled to a charitable deduction for the transaction.). See C.I.R. v. Duberstein, 363 U.S. 278, 280 (1960).

23. Allen, 541 at 788 (explaining that even though there is an element of quid pro quo in the transfer, the dominant purpose was to preserve the redwoods and, therefore, the taxpayer is still entitled to a charitable deduction). $\longleftarrow$

24. I.R.C. § 170 (2020). ‘

25. Treas. Reg. § 1.170A-15 (as amended in 2018).

26. I.R.C. $§ 5061$ (e) (2015) (An electronic fund transfer is a transfer of funds "initiated through an electronic terminal, telephonic instrument, or computer or magnetic tape so as to order, instruct, or authorize a financial institution to debit or credit an account.").

27. Online payment services include Square, Google Pay, and Stripe, to name a few. This can simply be the technology a vendor uses to collect payment online from a customer, such as an online clothing store. $\longleftarrow$

28. More than $60 \%$ of millennials have used a mobile payment application. Why Digital Donations Through Venmo and Cash App Have Exploded During the Pandemic, Fast Company, https://www.fastcompany.com/90567413/why-digital-donations-throughvenmo-and-cashapp-have-exploded-during-the-pandemic (last visited Dec. 17, 2020).

29. For simplicity, this article will use Venmo as the primary application, but this is not the only option or even the most popular. Each application will have different policies, but they follow the same federal regulations, so one has been chosen to reference. $\downarrow$

30. Nolan Murray, Breaking Benjamin: Security Threats in Mobile Payment Applications, 11 Ohio St. Bus. L.J. 1,4 (2017). $\longleftarrow$

31. Shelley E. Kohan, Fueled by Increased Consumer Comfort, Mobile Payments in The U.S. Will Exceed $\$ 130$ Billion in 2020, Forbes (Mar. 1, 2020, 6:10 AM), https://www.forbes.com/sites/shelleykohan/2020/03/01/fueled-by-increased-consumercomfort-mobile-payments-in-the-uswill-exceed-130-billion-in-2020/?sh=49e92d5a44f2 (last visited Dec. 15, 2020). ("The U.S. mobile payment market increased $41 \%$ from $\$ 69.8$ billion in 2018 to $\$ 98.8$ billion in 2019 ... [m]obile payments are increasingly being used by U.S. shoppers as customers become more comfortable with the technology.").

32. PayPal, https://www.paypal.com/us/webapps/mpp/non-profits/fundraising/donatebutton?CampaignName=VanityURL-DonateButton (last visited Dec. 15, 2020) (explaining 
how to streamline your fundraising: simple setup, fast processing, and easy payments).

33. What is Crowdfunding? The Clear and Simple Answer, GoFundMe, https://www.gofundme.com/c/crowdfunding (last visited Dec. 18, 2020) (illustrating the idea of crowdfunding: "Whether you want to help your pet, raise money to pay for a memorial, or get help with bills, crowdfunding can allow you to overcome the financial barriers that may stand in the way. While most people think crowdfunding services are only for individuals who need emergency financial assistance, businesses looking to fund a new project or raise capital can also fundraise online. Entrepreneurs can even use crowdfunding to finance projects or a new creative idea."). $\longleftarrow$

34. See supra Part I.

35. See supra Part I. $\longleftarrow$

36. I.R.C. $\S 501(c)(3)(2020)$.

37. Id. See How to Start a 501(c)(3) Nonprofit, Foundation Group, https://www.501c3.org/howto-start-a-501c3-nonprofit/\#: :text=To\%20obtain\%20501(c) (,one\%20completely\%20understands\%20the\%20process (last visited Dec. 16, 2020).

38. I.R.C. §501(a) (2020).

39. I.R.C. §501(c)(3) (2020).

40. Treas. Reg. §1.501(c)(3)-1 (as amended in 2017) (explaining the common law sense of the term charitable is for a public benefit). See I.R.C. §501(c)(3) (2020).

41. Treas. Reg. $\S 1.501$ (c)(3)-1 (explaining that the organizations' articles include "the trust instrument, the corporate charter, the articles of association, or any other written instrument by which an organization is created").

42. Id. ("An organization is organized exclusively for one or more exempt purposes only if its articles of organization...[l]imit the purposes of such organization to one or more exempt purposes; and [d]o not expressly empower the organization to engage, otherwise than as an insubstantial part of its activities, in activities which in themselves are not in furtherance of one or more exempt purposes.").

43. Id. (specifying that the operational test will not be satisfied for an action organization: (1) an organization with a significant part of its activities "attempting to influence legislation by propaganda or otherwise"; (2) an organization that "participates or intervenes, directly or indirectly, in any political campaign" for a candidate running for public office; or (3) an organization with its primary objective met only by legislation, and it campaigns for that objective "as distinguished from engaging in nonpartisan analysis, study, or research and making the results thereof available to the public"). See also I.R.C. §501(c)(3) (2020) 
(explaining an exempt purpose for an organization includes "religious, charitable, scientific, testing for public safety, literary, or educational purposes"). $\downarrow$

44. Treas. Reg. § 1.501(c)(3)-1. See also I.R.C. § 501(c)(3) (2020). $\nleftarrow$

45. Treas. Reg. $\S 1.501$ (c)(3)-1 (explaining that the organization must serve a public interest, "rather than a private interest"). $\longleftarrow$

46. Brinley v. Comm'r, 782 F.2d 1326, 1334 (5th Cir. 1986) ("To have control over donated funds is to have discretion as to their use."). $\longleftarrow$

47. I.R.C. $§ 170$ (2020) ("To or for the use of" means that the contribution must be made directly to a charitable organization or for the use of a charitable organization.).

48. Id. See Davis v. United States, 495 U.S. 472, 489 (1990) (holding that funds donated to specific individuals were not deductible as charitable contributions because the church did not have control of the donations). $\longleftarrow$

49. I.R.C. $§ 170$ (2020). See Davis, 495 U.S. at 477. Johnny R. Buckles, The Case for the Taxpaying Good Samaritan: Deducting Earmarked Transfers to Charity Under Federal Income Tax Law, Theory and Policy, 70 Fordham L. Rev. 1243, 1246 (2002). David L. Herron, A Tax Deduction for Direct Charitable Transfers: The Case Against Davis v. United States, 861 F.2d 558 (9th Cir. 1988), 64 Wash. L. Rev. 935, 940 (1989).

50. You can make a difference, American Red Cross, https://www.redcross.org/donate/donation.html/ (last visited Oct. 22, 2020).

51. Peace v. Comm'r of Internal Revenue, 43 T.C. 1, 3 (1964).

52. Id. at 2.

53. Id.

54. Id. at 7-8.

55. Id. at $8 . \leftarrow$

56. I.R.C. $\S 170$ (2020). Davis v. United States, 495 U.S. 472, 472 (1990).

57. Brinley v. Comm'r, 782 F.2d 1326, 1330 (5th Cir. 1986) (explaining that the court applied the 5th Circuit's standard set in Orr v. U.S. and concluding full control is not necessary for a deduction). See Orr v. United States, 343 F.2d 553, 557 (5th Cir. 1965) ("The charitable work must be the cause of the payment in order for the payment to be deductible."). $\downarrow$

58. Brinley, 782 F.2d at 1334-35 ("In these circumstances the charity has control and discretion because it has created a specific charitable cause and has solicited funds in support of that cause ... we conclude that a charitable organization's control is established where a specific charitable purpose is created and a donation is made in response to the charity's solicitation for funds in support of that purpose."). $\downarrow$ 
59. Davis, 495 U.S. at 472 ("holding that the payments were not "for the use of" the Church under $\S 170$ because the Church lacked sufficient possession and control of the funds.").

60. Id. at 481, 489 ("[I]t can be inferred that Congress' use of the phrase "for the use of" related to its purpose in amending $\S 170$ of allowing taxpayers to deduct contributions made to trusts, foundations, and similar donees. An interpretation of "for the use of" as conveying a similar meaning as "in trust for" would be consistent with this goal."). David L. Herron, A Tax Deduction For Direct Charitable Transfers: The Case Against Davis v. United States, 861 F.2d 558 (9th Cir. 1988), 64 Wash. L. Rev. 935, 946 (1989) (explaining the nonpossessory test as holding that physical control or possession of the donations is not a requirement for charity control, rather that the charity "established the charitable cause and selected the donation's beneficiary led to the conclusion of deductibility"). See Brinley, 782 F.2d at 1326. $\longleftarrow$

61. Bob Jones University v. U.S., 461 U.S. 574, 588 (1983).

62. Davis, 495 U.S. at 483-84 (“[A] taxpayer may generally claim an immediate deduction for a gift to a trustee, even though receipt of the gift by the charity is delayed. Recognizing this characteristic of gifts in trust, Congress further amended § 170 in 1964 in order to encourage donations "to" a charity, because donations "in trust for" a charity "often do not find their way into operating philanthropic endeavors for extended periods of time"”).

63. I.R.C. $§ 6115$ (1993) (“'Quid pro quo contribution’ means a payment made partly as a contribution and partly in consideration for goods or services provided to the payor by the done organization. A quid pro quo contribution does not include any payment made to an organization, organized exclusively for religious purposes, in return for which the taxpayer receives solely an intangible religious benefit that generally is not sold in a commercial transaction outside the donative context."). Haak v. U.S., 451 F. Supp. 1087, 1090 (W.D. Mich. 1978) (citing Oppewal v. Commissioner, 468 F.2d 1000, 1002 (1st Cir. 1972) ("The more fundamental objective test is...[W]as it, to any substantial extent, offset by the cost of services rendered to taxpayers...”)). See I.R.C. § 170 (2020).

64. Davis v. United States, 861 F. 2d 558, 562 (9th Cir. 1988), aff'd by 495 U.S. 472 (1990). See David L. Herron, A Tax Deduction For Direct Charitable Transfers: The Case Against Davis v. United States, 861 F.2d 558 (9th Cir. 1988), 64 Wash. L. Rev. 935, 945 (1989). •

65. See Davis, 495 U.S. at 486. See I.R.C. $\S 170$ (2020). «

66. Treas. Reg. § 1.170A-1(g) (as amended in 2020). See Davis, 495 U.S. at 486 (discussing the parent taxpayers' argument that transferring funds to their missionary sons' personal 
bank accounts was a contribution "to" the Church under 1.170A-1(g)).

67. Davis, 495 U.S. at 487. Treas. Reg. § 1.170A-1(g) (as amended in 2020). $\longleftarrow$

68. Davis, 495 U.S. at 486-88 (1990) ("The court [] rejected petitioners' alternative claim that the payments were deductible under Treas. Reg. 1.170A-1(g)-which allows the deduction of "unreimbursed expenditures made incident to the rendition of services to an organization contributions to which are deductible"-on the ground that petitioners were not themselves performing donated services."). See Treas. Reg. § 1.170A-1(g) (as amended in 2020). David L. Herron, A Tax Deduction For Direct Charitable Transfers: The Case Against Davis v. United States, 861 F.2d 558 (9th Cir. 1988), 64 Wash. L. Rev. 935, 944 (1989). $\longleftarrow$

69. I.R.C. $\S 170$ (2020). $\longleftarrow$

70. Id. $\longleftarrow$

71. GoFundMe is a platform to raise money by crowdfunding. See GoFundMe, http://www.gofundme.com (last visited Dec. 18, 2020).

72. I.R.C. § 170 (2020).

73. C.I.R. v. Glenshaw Glass Co., 348 U.S. 426, 426 (1955). •

74. See discussion infra Section III.C. $\longleftarrow$

75. Glenshaw Glass Co., 348 U.S. at 477. The recipient has (1) accession to wealth because the recipient is better off due to the gift, (2) clearly realized the gift as it was given to them, and (3) exercised complete dominion because the recipient has control over the gift.

76. I.R.C. $\S 102$ (2020). $\longleftarrow$

77. Id. $\triangleleft$

78. I.R.C. $\S 170$ (2020). $\longleftarrow$

79. DeJong v. Commissioner, 309 F.2d 373, 373, 374 (9th Cir. 1962) (explaining approximately $70 \%$ of the nonprofit's total income comes from the parents' contributions).

80. Id. at 375 . $\longleftarrow$

81. Id. at 375, 376. ("The law is well settled that tuition paid for the education of the children of a taxpayer is a family expense, not a charitable contribution to the educating institution.").

82. DeJong, 309 F.2d at 379. -

83. Haak v. U.S., 451 F. Supp. 1087, 1088, 1089 (W.D. Mich. 1978) (explaining that the Church would send out "Guidelines for Contributions," which broke down the costs for each family, and the total cost was the same for each family except the "School Plan Annual Cost," which varied with how many children the family had). 
84. Id. at $1088,1089,1091$ ("[W] here a transfer is made to a charitable organization with the exception of receiving a specific tangible benefit in return, there should be no deduction under section 170."). $\longleftarrow$

85. DeJong, 309 F.2d at 375; Haak, 451 at 1089. -

86. DeJong, 309 F.2d at 379; Haak, 451 at 1092.

87. See supra Part I. $\longleftarrow$

88. Conduit, Merriam-Webster, https://www.merriam-webster.com/dictionary/conduit (last visited Dec. 18, 2020) (defining a conduit as "a natural or artificial channel through which something ... is conveyed" or "a means of transmitting or distributing.").

89. I.R.C. § 170 (2020). ๘

90. C.I.R. v. Glenshaw Glass Co., 348 U.S. 426, 477 (1955).

91. See Id. $\longleftarrow$

92. See Ford Dealers Advertising Fund, Inc. v. Comm'r of Internal Revenue, 55 T.C. 761, 771 (1971) (holding that the funds collected by an individual acting as a conduit are not includable in gross income). $\longleftarrow$

93. Id. $\longleftarrow$

94. Id. $\longleftarrow$

95. Id. at 773 ("[T] he utilization of this [flow of water through a conduit] analogy shows that an intermediary may be employed as a depository for funds in trust which are destined for an ultimate use that is specified within defined limits.").

96. The conduit holding the excess funds intending to transfer it to or for the benefit of a charity would satisfy the "to or for the use of" requirement from I.R.C. § 170. $\downarrow$

97. I.R.C. § 170 (2020). $\longleftarrow$

98. Id. ("No deduction shall be allowed ... for any contribution of a cash, check, or other monetary gift unless the donor maintains as a record of such contribution a bank record or a written communication from the donee showing the name of the donee organization, the date of the contribution, and the amount of the contribution."). $\downarrow$

99. See supra Part I. $\longleftarrow$

100. I.R.C. $\S 170$ (2020). $\longleftarrow$

101. Id. Treas. Reg. $§ 1.170$ A-1(a) (as amended in 2020) ("Any charitable contribution, as defined in section 170 (c), actually paid during the taxable year is allowable as a deduction in computing taxable income irrespective of the method of accounting employed or of the date on which the contribution is pledged."). $\downarrow$

102. See generally C.I.R. v. Glenshaw Glass Co., 348 U.S. 426, 477 (1955). Taxpayer B is simply a channel between the contributor and the charitable organization and did not contribute 
their own money, so they are not entitled to a deduction. While it may be deemed that Taxpayer B clearly realized the funds because they received them, Taxpayer B does not have gross income because (1) there is not an accession to wealth because they are only holding the funds until the transfer and (2) there is not complete dominion because Taxpayer $B$ is not the intended beneficiary and only has control to transfer the funds to the designated charity. $\longleftarrow$

103. Treas. Reg. $§ 1.170 A-1$ (a)-(b) (as amended in 2020) (“[A] contribution is made at the time delivery is effected. The unconditional delivery or mailing of a check which subsequently clears in due course will constitute an effective contribution on the date of delivery or mailing."). $\longleftarrow$

104. Taxpayer B is not the intended beneficiary and does not have a gain or loss from the contributions. $\longleftarrow$

105. As discussed previously, Jane would not include the donations as gross income because the funds do not satisfy the Glenshaw Glass test. See generally Glenshaw Glass Co., 348 U.S. at 477 . $\longleftarrow$

106. If the taxpayer reports a deduction in the wrong taxable year, the taxpayer could be liable for penalties or even tax fraud. $\longleftarrow$

107. If the contributor finds out that the charity has not received their contribution from the conduit in the first taxable year, the contributor can file an amended tax return. If not amended, the contributor will likely face a penalty for mistakenly claiming the deduction.

108. Alternatively, Facebook has a feature that allows supporters to fundraise on behalf of the nonprofit and a feature to collect donations through the nonprofit's Facebook page. This supporter feature is similar to a social media post requesting donations and collecting the funds through a third-party mobile payment application, but Facebook allows users to set up a dedicated fundraising page to raise money. Using the Facebook supporter fundraisers tool, if the organization uses Facebook payments, the funds in the supporters' page will transfer into the organization's bank account bi-weekly by direct deposit or payout by $\mathrm{ACH}$. Using this feature, conduits would not find themselves in the situation of an overfunded charity and the charitable purpose no longer being available. However, this feature is new and is not used by the majority of conduits. See Facebook for Business, https://www.facebook.com/business/learn/lessons/tools-to-connect-donations-onfacebook (last visited Dec. 16, 2020). See also Social Media Giving Statistics for Nonprofits, Nonprofit Source, https://nonprofitssource.com/online-giving-statistics/social-media/ 
(last visited Dec. 18, 2020) ("18\% of donors worldwide have given through Facebook fundraising tools.”). $\longleftarrow$

109. Adler v. SAVE, 432 N.J. Super. 101, 104 (App. Div. 2013) (“[A] charity that solicits and accepts a gift from a donor, knowing that the donor's expressed purpose for making the gift was to fund a particular aspect of the charity's eleemosynary mission, is bound to return the gift when the charity unilaterally decides not to honor the donor's originally expressed purpose.").

110. Id. $\longleftarrow$

111. Id. at 125 ("[P]laintiffs placed their trust in SAVE to meet the conditions of their gift. By virtue of their control of the funds, SAVE was in a superior position to determine to either meet plaintiffs' conditions, request their consent to rededicate the funds to another purpose acceptable to plaintiffs, or return the gift."). 4

112. Id. at 126 (citing MacKenzie v. Trustees of the Presbytery of Jersey City, 67 N.J. Eq. 652, 67273 (1905)). $\longleftarrow$

113. Adler, 432 N.J. Super. at 104 ("[A] charity that solicits and accepts a gift from a donor, knowing that the donor's expressed purpose for making the gift was to fund a particular aspect of the charity's eleemosynary mission, is bound to return the gift when the charity unilaterally decides not to honor the donor's originally expressed purpose."). $\nleftarrow$

114. Facebook Messenger is a communication and instant-messaging platform. You can contact your Facebook friends and other Facebook accounts, depending on their privacy settings, much like you can contact someone using their personal phone number. $\downarrow$

115. User Agreement, Venmo, https://venmo.com/legal/us-user-agreement (last visited Dec. 18,2020 ) ("Venmo should only be used to transact with people you know and trust. Do not use Venmo to transact with people you don't know."). $\longleftarrow$

116. With over 2.7 billion monthly users as of September 30, 2020, and almost $75 \%$ of users visit daily, Facebook posts can be seen by a considerable amount of people proportionate to the number of shares the post receives and the number of friends the person who shared the post has. See Facebook Reports Third Quarter 2020 Results, Facebook, https://s21.q4cdn.com/399680738/files/doc_news/Facebook-Reports-Third-Quarter2020-Results-2020.pdf (last visited Dec. 17, 2020). $\longleftarrow$

117. The conduit would be able to return the funds but would not be able to contact the user through Venmo to ask permission for the funds to be given to a different charity. To return the funds, the conduit would go to the contributor's Venmo account and pay them the amount donated. $\leftarrow$ 
118. Fees, Venmo, https://venmo.com/about/fees (last visited Dec. 18, 2020) (Venmo does not charge fees for sending money from the user's Venmo balance, a linked bank account, or a debit card. If a payment is made by a credit card, then there is a 3\% transaction fee).

119. Create Your Account, Venmo, https://venmo.com/signup/email (last visited Oct. 23, 2020).

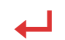

120. Nolan Murray, Breaking Benjamin: Security Threats in Mobile Payment Applications, 11 Ohio St. Bus. L.J. 1, 9 (2017). $\longleftarrow$

121. Privacy Policy, Venmo, https://venmo.com/legal/us-privacy-policy (last visited Dec. 18, 2020) ("We store and process your personal information using third party servers located in data centers in the United States. This information is protected by physical, electronic, and procedural safeguards in compliance with applicable US federal and state regulations. We also use computer safeguards such as firewalls and data encryption, we enforce physical access controls to our office and files, and we authorize access to personal information only for those employees who require it to fulfill their job responsibilities."). $\longleftarrow$

122. Kristopher C. Richardson, Mobile Payments in the United States: Are Regulations Adequately Protecting Consumers?, 6 No. 1 U. Puerto Rico Bus. L.J. 6, 15 (2014) ("Five financial regulatory agencies, however, do have limited regulatory oversight of mobile payments: Consumer Financial Protection Bureau (CFPB), Federal Deposit Insurance Corporation (FDIC), Federal Reserve System (FRS), National Credit Union Association (NCUA), and Office of the Comptroller of the Currency (OCC). Additionally, three other agencies have regulatory oversight over mobile payments: The Federal Trade Commission (FCC), the Federal Trade Commission (FTC), which have regulatory oversight with mobile payments when certain transactions or parties are involved, and the Financial Crimes Enforcement Network (FinCEN)."). $\longleftarrow$

123. Id. $\longleftarrow$

124. User Agreement, Venmo, https://venmo.com/legal/us-user-agreement/ (last visited Dec. 18,2020 ) ("We may share your mobile phone number with service providers with whom we contract to assist us with the activities listed above, but we will not share your mobile phone number with third parties for their own purposes without your consent."). See Privacy Policy, Venmo, https://venmo.com/legal/us-privacy-policy (last visited Dec. 18, 2020) ("Public information for personal profiles includes your Venmo username, profile photo, first and last name, month and year of Venmo account creation, and public transactions in which you've been involved."). $\leftrightarrow$ 
125. Venmo does allow for likes and comments on transactions, so the conduit could comment on the contributor's transaction requesting permission or contact information. However, the comment would be public and available for the Venmo network to have access to, which would probably not be realistic or secure. $\downarrow$

126. Venmo does not have an option to return a transaction. However, the conduit could make a transaction to the contributor for the amount originally donated. $\leftarrow$

127. 29 U.S.C. $§ 1109$ (1974) ("Any person who is a fiduciary with respect to a plan who breaches any of the responsibilities, obligations, or duties imposed upon fiduciaries by this subchapter shall be personally liable to make good to such plan any losses to the plan resulting from each such breach, and to restore to such plan any profits of such fiduciary which have been made through use of assets of the plan by the fiduciary, and shall be subject to such other equitable or remedial relief as the court may deem appropriate, including removal of such fiduciary."). 4

128. Even though a court is likely to find for the conduit in a situation where they donated the funds to a similar use when they were stuck with a pool of funds intended for a specific charity that was overfunded, the hassle of a lawsuit could be avoided by one of the proposed solutions described below. $\longleftarrow$

129. User Agreement, Venmo.com, https://venmo.com/legal/us-user-agreement (last visited Oct. 15, 2020).

130. Id. $\longleftarrow$

131. See supra Part I. $\longleftarrow$

132. I.R.C. § 170 (2020). See Treas. Reg. § 1.170A-1(a) (as amended in 2020) (“Any charitable contribution, as defined in section 170 (c), actually paid during the taxable year is allowable as a deduction in computing taxable income irrespective of the method of accounting employed or of the date on which the contribution is pledged.").

133. I.R.C. § 170 (2020). «

134. Id. (The charitable contribution must be "to or for the use of" a qualifying organization and to be a qualifying organization, it must be "organized and operated exclusively for religious, charitable, scientific, literary, or educational purposes").

135. Treas. Reg. $§ 1.170 A-1$ (a)-(b) (as amended in 2020) (“[A] contribution is made at the time delivery is effected. The unconditional delivery or mailing of a check which subsequently clears in due course will constitute an effective contribution on the date of delivery or mailing."). $\longleftarrow$

136. Adler v. SAVE, 432 N.J. Super. 101, 104 (App. Div. 2013) (“[A] charity that solicits and accepts a gift from a donor, knowing that the donor's expressed purpose for making the 
gift was to fund a particular aspect of the charity's eleemosynary mission, is bound to return the gift when the charity unilaterally decides not to honor the donor's originally expressed purpose.").

137. See supra Part I. $\longleftarrow$

138. See supra Part I. $\longleftarrow$

139. C.I.R. v. Glenshaw Glass Co., 348 U.S. 426, 477 (1955) (explaining that there are three elements to satisfy the test for gross income: if it is an undeniable accession to wealth, clearly realized, and over which the taxpayers have complete dominion). $\downarrow$

140. See supra Part V. $\longleftarrow$

141. See supra Part V. $\leftarrow$

\section{Leave a Reply}

Your email address will not be published. Required fields are marked *

Comment

Name *

Email *

Website

Save my name, email, and website in this browser for the next time I comment. 


\section{RECENT POSTS}

What To Do With Leftovers: Collecting Earmarked Donations Through Mobile Payment Apps

Chadwick v. Comm'r

Ruesch v. Comm'r

Using Tax Law to Perpetuate Gentrification: Vinegar Hill Lives Again in Charlottesville Laidlaw's Harley Davidson Sales, Inc. v. Comm'r

\section{RECENT COMMENTS}

\section{ARCHIVES}

January 2022

May 2021

April 2021

March 2021

January 2021

December 2020

November 2020

October 2020

September 2020

August 2020

July 2020

June 2020 
May 2020

April 2020

March 2020

February 2020

January 2020

\section{CATEGORIES}

Addition Tax

Appraisal Summary

Articles

Attorney Fees

BEAT

Business Expense

Capacity

Car and Truck Expenses

Case Summary

Charitable Contribution

Charitable Deduction

Civil Procedure

Civil Tax Penalties

Collections Due Process

Constitutional Law

Contracts

Criminal Law

DC Circuit

Deceased Debtor

Deductions 
Delinquencies

Divorce

Eight Circuit

Employment Tax

ERISA

Estate Planning

Evidence

Federal Rate Deduction

Form 8283

GGU Presents

GILTI

In Terrorem Clause

Insurance

Intent of Transferee

Interview

IRA

IRS Examinations

Life Insurance

Lodging, Meals, \& Incidentals

Luxury Water Travel

Mobile Payments

Ninth Circuit

NOL

Ohio Uniform Fraudulent Transfer Act

Online Payments

Opportunity Zones

Overfunded Charities

Penalties 
Penalty Procedures

Preemption

Privacy

Probate

Real Estate

Responsible Person

Schedule C

SCOTUS

Second Circuit

Self-Employment

Standard of Review

Stock

Strict Compliance

Student Blog

Summary Judgment

Tax

Tax Lien

Tax Return

TCJA

Travel Expenses

Trust Fund Recovery Penalty

Trusts

Uncategorized

US Tax Court

Whistleblower

Wills

META 
Log in

Entries feed

Comments feed

WordPress.org

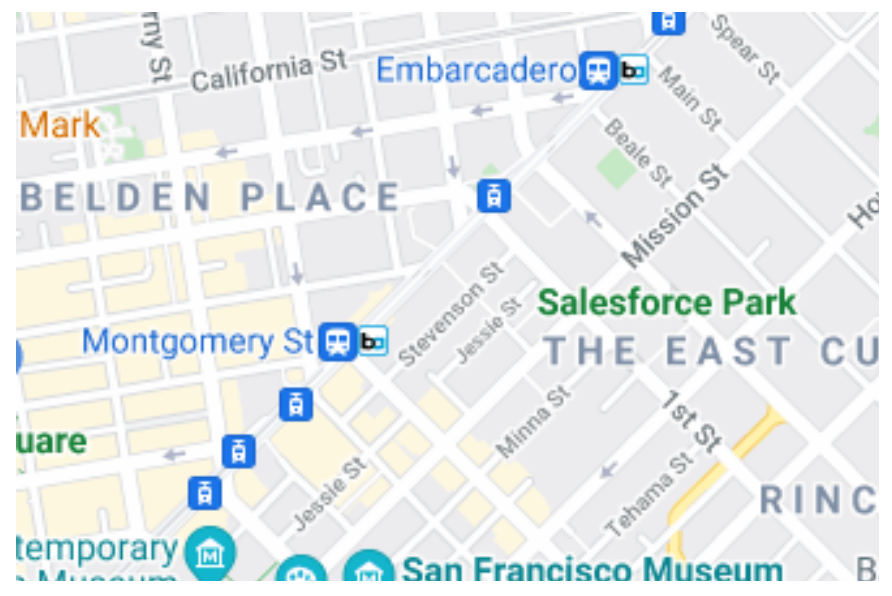

CONTACT US!

Via our contact form or

through the avenues below.

GGU Tax \& Estate

Planning Review

Golden Gate University

School of Law

536 Mission Street

San Francisco, CA 94105

ContactTaxReview@ggu.edu

Search ... 
TAGS

California Connecticut Florida Georgia Minnesota New York North Carolina Ohio

Oklahoma Oregon Pennsylvania Texas USTC Virginia Washington

Privacy Policy

๑) Golden Gate University Tax \& Estate Planning Review 